International Journal of Environment, Agriculture and Biotechnology
Vol-7, Issue-1; Jan-Feb, 2022
J Journal Home Page Available: $\underline{\text { https://ijeab.com/ }}$
Journal DOI: $10.22161 /$ ijeab

Peer Reviewed

\title{
Revenue Analysis and Marketing of Seaweed (Kappaphycus alvarezii) in Wajo Regency
}

\author{
Andi Utami Batari ${ }^{1}$, Sutinah $^{2}$, Sri Suro Adhawati ${ }^{3}$
}

${ }^{1}$ Students of the Postgraduate Program in Fisheries Science at Hasanuddin University, Makassar
${ }^{2,3}$ Lecturers in the Postgraduate Program in Fisheries Science at Hasanuddin University, Makassar

Received: 10 Dec 2021; Received in revised form: 07 Jan 2022; Accepted: 12 Jan 2022; Available online: 18 Jan 2022

(C)2022 The Author(s). Published by Infogain Publication. This is an open access article under the CC BY license

(https://creativecommons.org/licenses/by/4.0/).

\begin{abstract}
Seaweed (Khappaphycus alvarezii) is a fishery commodity that is in great demand in the world. South Sulawesi is one of the largest seaweed-producing areas in Indonesia and Wajo Regency occupies the first position with the largest production of 433,817.4 tons/year, however, it is still experiencing several obstacles, starting from the selection of land/location, seeds, pests and diseases, institutions, limitations capital, marketing and processing. This study aims to analyze the level of income and marketing of seaweed (K. alvarezii) cultivation in Wajo Regency. This research uses income and marketing analysis. The results showed that the total profit of seaweed cultivators in one year of production was IDR 176,111.484, - where, on a land area of $<1$ ha, the cultivators earned an annual profit of IDR 50,704,769, - and for a land area of 1-2 ha, the cultivators earn an annual profit of IDR 125,406,714, -. Based on the results of marketing analysis, marketing costs incurred are IDR 123, -/Kg for collectors. The marketing margin received by the collecting traders is IDR 1,500,-/Kg. Seaweed marketing in Wajo Regency is considered efficient because based on the results of the study obtained a value of $0.55 \%$, which means the value is less than 1 , which is caused by the short number of marketing chains.
\end{abstract}

Keywords - Cultivation, Income, Marketing, Seaweed.

\section{INTRODUCTION}

Seaweed is one of the various species of marine biota in Indonesia. The species richness of this seaweed does not only play a role in maintaining the balance of the ecosystem but its benefits can be taken, including as a raw material for the cooking industry, cosmetics, construction industry, pharmaceuticals, health and medicine, seaweed is also one of the leading products in government policies (Akil et al ., 2015). Seaweed is an important fishery product that has the potential to significantly improve the community's economy but has not been fully utilized (Troell et al., 2006; Le Gouvello et al., 2017).

Seaweed cultivation has been cultivated in many countries including Indonesia because it is considered a strategic commodity (Kordi and Ghufron., 2011; Bhakti, FK et al., 2016). Nurmaena (2017) argues that seaweed business causes changes in social and economic structures, especially in community livelihood activities in coastal areas. Seaweed cultivation is a commodity in the mangrove ecosystem that has market value (Fruteau et al., 2009; Priambodo and Najib, 2014; Adhawati 2021), cultivation is also influenced by the equipment used (Meijer et al., 2015). Seaweed cultivation in South Sulawesi Province is growing rapidly because of its high economic value and utilization rate that is useful as food and raw material for the carrageenan industry. The increased use of seaweed extract will have a positive impact on the demand for seaweed production, so a better seaweed business system is needed to meet this demand (Amiluddin et al., 2007). South Sulawesi is one of the largest seaweed producing areas in Indonesia, including the districts of Wajo, Takalar, Pangkajene and the Islands, Bone, Barru and Jeneponto.

Wajo Regency occupies the first position for the largest seaweed production in South Sulawesi with a total production of 433,817.4 tons/year (DKP SULSEL, 2021). The data collected states that there are six sub-districts in Wajo that exist to produce seaweed, including the Districts of Penrang, Bola, Takkalalla, Pitumpanua and Sajoanging and 
Keera (BPS, 2021). Based on its potential, Wajo Regency is a seaweed-producing area that has the potential to be developed but in practice there are still several obstacles ranging from land selection, seeds, pests/diseases, institutions, limited capital, marketing and processing (Roni, 2016), direct marketing to collectors who already have market access. According to Anh (2021), in evaluating the welfare of farmers, the level of marketing and income generated by cultivation are two important factors. Seaweed cultivation carried out by cultivators requires integration between subsystems, starting from the provision of production inputs, cultivation to marketing of seaweed. This can be achieved through cooperation between the relevant parties. Based on the description above, the purpose of this study is to analyze the level of income and marketing of seaweed (K. alvarezii) cultivation in Wajo Regency.

\section{METHODOLOGY}

\section{A. Location and Time of Research}

This research will be carried out in Wajo Regency, South Sulawesi for four months from February to May 2021. The selection of this research location was carried out purposively based on the consideration that the location was chosen because it has great seaweed potential and has the potential to be further developed.

\section{B. Sampling Method}

The population in this study were seaweed farmers in Wajo Regency. The total population of seaweed cultivators in Wajo Regency is 2,656 people. Sampling was carried out using themethod, proportional sampling meaning that samples were taken from the entire population, according to the proportions of each sub-population so that the samples taken could represent each sub-population and each farmer had the same opportunity to be selected as a sample (Parel et al. , 1973; Purnamasari 2010). The sample criteria in this study were seaweed cultivators who were still actively engaged in aquaculture. The number of respondents determined using the Slovin formula was 44 respondents.

Determination of samples for collectors who are involved in marketing seaweed in Wajo Regency is determined by the snowball sampling method, namely based on information from the respondents, then based on those appointed by the respondents, and so on until the saturation of the sample or sample is difficult to achieve. This model is used because the target population of traders is not known clearly and is difficult to detect in other ways.

\section{Types and Sources of Data}

This Type of research is survey research. Survey research is research that takes a sample from one population and uses a questionnaire as the main data collection tool
(Singarimbun, 2008).

The data sources used in this study are primary data and secondary data. Primary data sources were obtained through documentation and interviews with seaweed cultivators and traders, which included analysis of income levels and marketing. Secondary data is obtained from literature studies or literature studies that are relevant or related to research, data from the Fisheries Service and the Central Bureau of Statistics of Wajo Regency, report results, and previous research that can support research studies.

\section{Data Analysis}

Methods Qualitative methods are carried out in descriptive analysis which according to (Sugiyono, 2013) is a method that serves to describe or provide an overview of the object under study through data or samples that have been collected as they are without analyzing and making conclusions that apply to general. Descriptive analysis was used to describe the seaweed cultivation business in Wajo Regency.

To analyze the data that has been obtained, the following data analysis is used:

\section{Income analysis}

To determine the amount of production and profits received from seaweed cultivation, the following equation is used (Bangun, 2010):

$$
\pi=\mathrm{TR}-\mathrm{TC}
$$

Where:

$$
\begin{aligned}
T \mathrm{~T} & =\text { Net Profit }(\mathrm{Idr}) \\
\mathrm{TR} & =\text { Total Revenue }(\mathrm{Idr}) \\
\mathrm{TC} & =\text { Total Cost }(\mathrm{Idr})
\end{aligned}
$$

To find Total Revenue, the formula (Bangun, 2010):

$$
\mathrm{TR}=\mathrm{Q} \times \mathrm{P}
$$

Where:

$\mathrm{TR}=$ Total Revenue $(\mathrm{Idr})$

$\mathrm{P}=$ Price $(\mathrm{Idr}$

$\mathrm{Q}=$ Quantity (Amount) (Kg)

Meanwhile, to find the Total Cost, the formula (Bangun, 2010):

$$
\mathrm{TC}=\mathrm{FC}+\mathrm{VC}
$$

Where:

$$
\begin{aligned}
\mathrm{TC} & =\text { Total Cost }(\text { Total Cost })(\mathrm{Rp}) \\
\mathrm{VC} & =\text { Variable CostVariable Cost }()(\mathrm{Rp}) \\
\mathrm{FC} & =\text { Fixed CostFixed Cost }()(\mathrm{Rp})
\end{aligned}
$$

\section{R/C Ratio Analysis}


$\mathrm{R} / \mathrm{C}$ ratio is a comparison between total revenue and total cost, which shows the value of receipts obtained from each rupiah issued. The $\mathrm{R} / \mathrm{C}$ ratio can be formulated as follows (Soekartawi, 2002):

$$
R / C=\frac{T R}{T C}
$$

Description:

$\mathrm{TR}=$ Total Revenue

$\mathrm{TC}=$ Total Cost

\section{Criteria Rating R / C Ratio:}

$\mathrm{R} / \mathrm{C}<1=$ business suffers a loss

$\mathrm{R} / \mathrm{C}>1$ = business gains profit

$\mathrm{R} / \mathrm{C}=1$ = business reaches the break-even point

\section{Marketing analysis}

To calculate marketing margin, marketing costs and marketing efficiency of seaweed cultivation in Wajo Regency, use The calculation is as follows:

\section{Marketing Margin}

$$
\mathrm{Mp}=\operatorname{Pr}-\mathrm{Pf}
$$

Description:

Mp : Marketing Margin

$\operatorname{Pr}$ : Price at consumer level (Rp)

Pf : Price at producer level (Rp)

\section{Marketing Cost}

To calculate marketing costs using the formula (Soekartawi, 2002):

$$
\mathrm{Bp}=\mathrm{Bp1}+\mathrm{Bp2}+\mathrm{Bp3}+\ldots . . .+\mathrm{Bpn}
$$

Remarks :

Bp : Marketing costs for seaweed

Bp1, Bp2, Bp3..Bpn : Marketing costs for each seaweed marketing agency. Marketing Efficiency

To calculate marketing efficiency using the formula (Soekartawi, 2002):

$$
\text { Eps }=\frac{\text { Total Marketing Cost }}{\text { Marketed Product Value }} \boldsymbol{x} 100 \%
$$

The $<$ Ep value obtained means the more efficient the marketing chain $(<1$ : Efficient, $>1$ : Inefficient).

\section{RESULTS AND DISCUSSION}

The production process is very important because this process involves the stages of activities in running theseaweed cultivation business $K$. alvarezii which can determine level of quality and quantity of seaweed produced. The stages of production of $K$. alvarezii are as follows:

\section{1) Land Preparation and Seedling}

Furthermore, the preparation of seeds in a good selection is used as seaweed seeds for 2-3 days.

\section{2) Tie Seaweed}

After preparing the land and seeds, the next step is tying the seeds on the rope that has been prepared. The selected seeds are then tied to a rope that has been prepared for 3 days. The seeds that have been tied up are immediately taken to the sea and then spread out in the waters (done in stages). The seeds used are usually $6 \mathrm{~kg}-7 \mathrm{~kg}$ of seeds per one stretch, one stretch of 25 meters long.

3) Installation of seeds on a stretch rope and planting

Installation of seeds on a stretch rope, the seeds that have been tied to the rope are then brought to land located on the sea coast for 1-3 days, Usually the seeds that have been tied are immediately taken to the waters to be planted. spread out. The cultivators spread the seeds with the help of other cultivators as many as 2-3 people so that they are not too long at sea, then return to land or the seaweed check point to retrieve the seeds that have been tied (this process is carried out in stages).

The criteria for seaweed used as seeds are seaweed thallus which is morphologically clean and fresh, characterized by hard and brightly colored thallus, 25-35 days old, free from disease (no spots, not peeling, bright specific color), and tallus has many branches, thick and slightly pointed ends (Cokrowati, 2020).

4) Maintenance

Maintenance includes cleaning dirt by moving (cleaning) each stretch that has been installed, replacing damaged plants with better ones, repairing damaged or broken ropes. This check is carried out about 1-3 times a week by boat to the waters where seaweed is cultivated.

\section{5) Harvesting}

The seaweed harvesting stage is carried out in stages usually lasting for 2-3 days depending on the number of stretches installed, this is due to uncertain natural conditions. Harvesting is done when the seaweed is approximately 28-30 days old to be used as seeds, while the harvest used for sale is generally when the seaweed is a maximum of 40 days. According to Nor (2020) fresh seaweed is used as a source of seeds or propagules, and dried seaweed is used as raw material in the extraction of carrageenan. Harvesting is done by transferring all the plants to a boat, then brought to the house or lodge using a cart (dompeng) and harvesting is done 3 times a year.

6) Postharvest, 
Post-harvest handling is done by releasing the seaweed from the stretch rope, then drying (drying) the seaweed for approximately 3-4 days or depending on weather conditions, if it rains the drying can last about 1 week or even more. After drying, the seaweed is ready to be put into sacks and then stored in the warehouse (cultivator's house). Next, cultivators contact collectors to collect seaweed.

\section{Income Analysis}

Soekartawi (2006) Explains that income will affect the amount of goods consumed, that it is often encountered with increasing income, the goods consumed not only increase, but also the quality of the goods is also a concern. Revenue is the difference between receipts and all costs (Bangun, 2010).

\section{Investment in Cultivation Business K. alvarezii}

Investment is investment in an activity that has a relatively long period of time in various business fields (Amiluddin et al., 2020). To see the amount of investment in seaweed cultivation, it can be seen in table 1 . below :

Table 1. Investment Components for seaweed cultivators with a land area of $<1 \mathrm{Ha}$.

\begin{tabular}{|c|c|c|c|c|c|}
\hline No. & Investment Type & $\begin{array}{c}\text { Technical } \\
\text { Age }\end{array}$ & $\begin{array}{l}\text { Total } \\
\text { (Unit) }\end{array}$ & Cost (IDR) & $\begin{array}{c}\text { Percentage } \\
(\%)\end{array}$ \\
\hline 1 & Boat & 10 Years & 1 & $17,769,231$ & 52.95 \\
\hline 2 & Machine & 4 Years & 1 & $8,192,308$ & 24.41 \\
\hline 3 & Anchor Rope (string no.8) & 1 Years & 14 & 723,077 & 2.15 \\
\hline 4 & Anchor & 1 Years & 29 & 144,231 & 0.43 \\
\hline 5 & Foundation Buoy (5 liter jerrycan) & 1 Years & 14 & 50,615 & 0.15 \\
\hline 6 & Stretch Buoy (1.5 ltr mineral bottle) & 1 Years & 462 & 230,769 & 0.69 \\
\hline 7 & Float (600 ml mineral bottle) & 1 Years & 1,154 & 403,846 & 1.20 \\
\hline 8 & Stretch rope (line no.5) & 1 Years & 83 & $4,157,692$ & 12.39 \\
\hline \multirow[t]{2}{*}{9} & Drying equipment (para-para size 8x10 m) & 1 Years & 1 & $1,884,615$ & 5.62 \\
\hline & Total Investment & & & $33,556,385$ & 100 \\
\hline
\end{tabular}

Source: Primary data after processing, 2021

Based on table 1. it can be seen that the total investment required by cultivators is IDR $33,556,385$, - with the highest component value, namely for the purchase of machines of IDR 17,769,231,- with a presentation of $52.95 \%$. While the lowest component is the purchase of a foundation buoy (5 liter jeregen) of IDR 50,615, - with a presentation of $0.15 \%$. The investment components used by seaweed farmers for a full year with a land area of 1-2 hectares can be seen in Table 2.

Table 2. Investment Components for seaweed cultivators with a land area of 1-2 Ha.

\begin{tabular}{|c|c|c|c|c|c|}
\hline No. & Investment Type & $\begin{array}{c}\text { Technical } \\
\text { Age }\end{array}$ & $\begin{array}{c}\text { Total } \\
\text { (Unit) }\end{array}$ & Cost (IDR) & $\begin{array}{c}\text { Percentage } \\
(\%)\end{array}$ \\
\hline 1 & Boat & 10 Years & 1 & $19,274,194$ & 46.48 \\
\hline 2 & Machine & 4 Years & 1 & $8,580,645$ & 20.69 \\
\hline 3 & Anchor Rope (string no.8) & 1 Years & 30 & $1,516,129$ & 3.66 \\
\hline 4 & Anchor & 1 Years & 59 & 294,355 & 0.72 \\
\hline 5 & Foundation Buoy (5 liter jerrycan) & 1 Years & 31 & 106,129 & 0.26 \\
\hline 6 & Stretch Buoy (1.5 ltr mineral bottle) & 1 Years & 942 & 470,968 & 1.14 \\
\hline 7 & Float (600 ml mineral bottle) & 1 Years & 2,355 & 824,194 & 1.99 \\
\hline 8 & Stretch rope (line no.5) & 1 Years & 171 & $8,530,645$ & 20.57 \\
\hline \multirow[t]{2}{*}{9} & Drying equipment (para-para size $8 \times 10 \mathrm{~m}$ ) & 1 Years & 1 & $1,870,968$ & 4.51 \\
\hline & Total Investment & & & $41,468,226$ & 100 \\
\hline
\end{tabular}

Source: Primary data after processing, 2021 
Based on table 2. it can be seen that the total investment required by seaweed farmers is IDR 41,468,226 with the highest component value, namely for the purchase of a boat of IDR 19,274,194 with a presentation of $46.48 \%$. While the lowest component is the purchase of a foundation buoy ( 5 liter jeregen) of IDR 106.129 with a presentation of $0.26 \%$.

\section{Fixed Costs}

Fixed costs are costs that do not depend on the volume of production because these costs continue to be issued, although the harvest of seaweed farming gained a lot or a little (Earth, 2015). The components of the fixed cost of seaweed cultivation for a full year with a land area of $<1 \mathrm{Ha}$ can be seen in Table 3 .

Table 3. Fixed Cost Components of Seaweed Cultivation for a Full Year with a land area of $<1 \mathrm{Ha}$

\begin{tabular}{clcc}
\hline No. & \multicolumn{1}{c}{ Output type } & Cost (IDR) & Percentage (\%) \\
\hline 1 & Boat Shrink & $1,776,923$ & 14.40 \\
2 & Machine Shrink & $2,048,077$ & 16.59 \\
3 & Anchor Rope Shrinkage (string no.8) & 723,077 & 5.86 \\
4 & Anchor Shrinkage & 144,231 & 1.17 \\
5 & Depreciation of Foundation Buoys (5 liter jeregen) & 50,615 & 0.41 \\
6 & Stretch Buoy Shrinkage (1.5 ltr mineral bottle) & 230,769 & 1.87 \\
7 & Shrinkage Float (600 ml mineral bottle) & 403,846 & 3.27 \\
8 & Stretch rope shrinkage (line no.5) & $4,157,692$ & 33.68 \\
9 & Depreciation of drying equipment (para-para size 8x10 m) & 807,692 & 6.54 \\
10 & Maintenance cost & $2,000,000$ & 16.20 \\
\hline
\end{tabular}

Source: Primary data after processing, 2021

The total fixed cost with a land area of $<1$ Ha for a full year is IDR $12,342,923$, - where the highest component value is the cost of stretching ropes (rope no.5) of IDR $4,157,692$, - with a presentation of $33.36 \%$. While the lowest component is the depreciation of the foundation buoy ( 5 liter jeregen) of IDR 50,615, - with a presentation of $0.41 \%$. The components of fixed costs for seaweed cultivation for a full year with a land area of 1-2 Ha can be seen in Table 4.

Table 4. Fixed Cost Components of Seaweed Cultivation for a Full Year with a land area of 1-2 Ha

\begin{tabular}{clcc}
\hline No. & \multicolumn{1}{c}{ Output type } & Cost (IDR) & Percentage (\%) \\
\hline 1 & Boat Shrink & $1,927,419$ & 9.90 \\
2 & Machine Shrink & $2,145,161$ & 11.02 \\
3 & Anchor Rope Shrinkage (string no.8) & $1,516,129$ & 7.79 \\
4 & Anchor Shrinkage & 294,355 & 1.51 \\
5 & Depreciation of Foundation Buoys (5 liter jeregen) & 106,129 & 0.55 \\
6 & Stretch Buoy Shrinkage (1.5 ltr mineral bottle) & 470,968 & 2.42 \\
7 & Shrinkage Float (600 ml mineral bottle) & 824,194 & 4.23 \\
8 & Stretch rope shrinkage (line no.5) & $8,530,645$ & 43.82 \\
9 & Depreciation of drying equipment (para-para size 8x10 m) & $1,064,516$ & 5.47 \\
10 & Maintenance cost & $2,587,097$ & 13.29 \\
\hline
\end{tabular}

Source: Primary data after processing, 2021

Total fixed cost of seaweed cultivation with a land area of 1-2 Ha a full year is IDR $19,466,613$ where the highest component value is the depreciation cost of stretched rope (line no. 5) of IDR 8,530 .645,- with a presentation of 
$43.82 \%$. While the lowest component is the depreciation of the foundation buoy (5 liter jeregen) of IDR 106,129, - with a presentation of $0.55 \%$.

\section{Variable costs}

Variable costs are costs when linked to volume per unit will always remain despite production volume change, but the total cost of the numbers will change in proportion to changes in activity. If the production is low, the variable costs are small and vice versa, which includes the variable costs in seaweed cultivation activities using the longline technique are seeds, consumption, fuel, labor wages, fasteners and wages for tailors. Expenditures on variable costs for seaweed cultivation with an area of $<1 \mathrm{Ha}$ in one year can be seen in table 5 .

Table 5. Variable Cost Compensation for seaweed cultivation with a land area of $<1$ Ha in one year

\begin{tabular}{|c|c|c|c|}
\hline No. & Output type & Biaya (IDR) & Persentasi (\%) \\
\hline 1 & Seeds & $19,384,615$ & 66.33 \\
\hline 2 & Consumption & $2,569,231$ & 8.79 \\
\hline 3 & Fuel oil & $1,038,462$ & 3.55 \\
\hline 4 & Bonding Labor Wages & $2,769,231$ & 9.48 \\
\hline 5 & Wages of a stretch rope tailor & $3,461,538$ & 11.85 \\
\hline \multicolumn{2}{|r|}{ Total Variabel Cost } & 29,223,077 & 100 \\
\hline
\end{tabular}

Source: Primary data after processing, 2021

The total variable cost is IDR 29,223,077. The variable costs with the highest component value are seeds of IDR $19,384,615$ or $66.33 \%$, while the variable costs that 1,038,462, - or $3.55 \%$. Expenditures on variable costs for seaweed cultivation with an area of $<1 \mathrm{Ha}$ in one year can be seen in Table 6. have the lowest component value are fuel, which are IDR

Table 6. Variable Cost Compensation for seaweed cultivation with a land area of 1-2 Ha in one year

\begin{tabular}{|c|c|c|c|}
\hline No. & Output type & Biaya (IDR) & Persentasi (\%) \\
\hline 1 & Seeds & $38,038,796$ & 69.55 \\
\hline 2 & Consumption & $2,391,070$ & 4.37 \\
\hline 3 & Fuel oil & $2,037,793$ & 3.73 \\
\hline 4 & Bonding Labor Wages & $5,434,114$ & 9.94 \\
\hline 5 & Wages of a stretch rope tailor & $6,792,642$ & 12.42 \\
\hline & Total Variabel Cost & $54,694,415$ & 100 \\
\hline
\end{tabular}

Source: Primary data after processing, 2021

The total variable cost with a land area of 1-2 Ha is IDR 54,694,415, -. The variable costs that have the highest component value are seeds of IDR $38,038,796$, - or $69.55 \%$. The variable cost which has the lowest component value is BBM, which is IDR 2,037,793, - or $3.73 \%$.

\section{Total Cost}

Total costs are all costs sacrificed which is the total fixed costs plus variable costs. The average total costs incurred by seaweed cultivators in Wajo Regency in one year can be seen in Table 7 .

Table 7. Total Cost/Year of seaweed production in Wajo Regency

\begin{tabular}{ccccc}
\hline No. & Land area & Total Fixed Cost (IDR) & Total Variable Cost (IDR) & Total Cost (IDR) \\
\hline 1 & $<1 \mathrm{Ha}$ & $12,342,923$ & $29,223,077$ & $41,566,000$ \\
2 & $1-2 \mathrm{Ha}$ & $19,466,613$ & $54,694,415$ & $74,161,028$ \\
\hline \multicolumn{2}{r}{ Total Cost } & & & $\mathbf{1 1 5 , 7 2 7 , 0 2 8}$
\end{tabular}

Source: Primary data after processing, 2021

Based on Table 7, it can be seen that the total cost in one year is IDR $115,727.028$, -. The total cost for a land area of $1 \mathrm{Ha}$ is IDR $41,566,000$, - and for a land area of 1-2 Ha, which is IDR 74.161.028, - 


\section{Revenue}

Revenue is the total amount produced multiplied by the price prevailing at that time. The amount of production and price of seaweed in each area is different. The average value of production revenue in one year can be seen in Table 8.

Table 8. Total Revenue/Year of seaweed cultivators in Wajo Regency No Land area Total

\begin{tabular}{lcccc}
\hline No & Land area & Total Production $\mathbf{( K g )}$ & Price $(\mathbf{K g})$ & Total Revenue (IDR) \\
\hline 1 & $<1 \mathrm{Ha}$ & 4,394 & 21,000 & $92,270,769$ \\
2 & $1-2 \mathrm{Ha}$ & 9,503 & 21,000 & $199,567,742$ \\
\hline
\end{tabular}

Total Revenue

$\mathbf{2 9 1 , 8 3 8 , 5 1 1}$

Source: Primary data after processing, 2021

Based on table 8 . the total revenue of seaweed cultivators in one year is IDR 291,838,511 with the highest revenue on a land area of 1-2 ha of IDR 199,567,742

Profit

Net income is the difference between the sales of production andcosts. Income analysis is used to determine the

Table 9. Total Profits/Year of seaweed cultivators in Wajo Regency

\begin{tabular}{crccc}
\hline No. & Land area & Total Revenue (IDR) & Total Cost (IDR) & Total Income (IDR) \\
\hline 1 & $<1 \mathrm{Ha}$ & $92,270,769$ & $41,566,000$ & $50,704,769$ \\
2 & $1-2 \mathrm{Ha}$ & $199,567,742$ & $74,161,028$ & $125,406,714$ \\
\hline \multicolumn{2}{c}{ Total Income } & $\mathbf{1 7 6 , 1 1 1 , 4 8 4}$ \\
\hline
\end{tabular}

Source: Primary data after processing, 2021

Based on table 9. the total profit of seaweed cultivators in one year of production is IDR 176.1111.484,-Where, on a land area of $<1 \mathrm{Ha}$, the cultivator earns an annual profit of IDR 50,704,769, - and on a land area of 1-2 Ha, the cultivator earns an annual profit of IDR 125,406.714,-

\section{Revenue and Cost Balance Analysis (R/C ratio)}

The analysis of the balance of revenues and costs (R/C) aims to determine the results obtained from a business activity. If $\mathrm{R} / \mathrm{C}>1$, then the business makes a profit, if $\mathrm{R} / \mathrm{C}<$ 1 then the business suffers a loss and if $\mathrm{R} / \mathrm{C}=1$ then the business is at the break-even point.

1. $\mathrm{R} / \mathrm{C}$ ratio for land area $<1 \mathrm{Ha}$

Calculation of the analysis of the $\mathrm{R} / \mathrm{C}$ ratio in the cultivation of K. alvarezii seaweed in Wajo Regency can be seen as follows:

$$
\begin{gathered}
\mathrm{R} / \mathrm{C}=\mathrm{TR} / \mathrm{TC} \\
\mathrm{R} / \mathrm{C}=\frac{\text { IDR } 92,270,769}{\text { IDR } 41,566,000} \\
\mathrm{R} / \mathrm{C}=2.22
\end{gathered}
$$

The total income received by seaweed farmers in Wajo Regency which is produced is IDR 92,270,769, - and the total cost incurred is IDR $41,566,000,-$. Based on the description above, it can be stated that the cultivation of $\mathrm{K}$. alvarezii seaweed in Wajo Regency is good and can be run because the $\mathrm{R} / \mathrm{C}$ ratio obtained is 2.22 , where if the $\mathrm{R} / \mathrm{C}$ profit earned per year. Each cultivator has a different amount of profit because the calculation of

profits is influenced by the total cost component and the revenue component. For more details, the benefits of seaweed cultivators in one year can be seen in Table 9. obtained is more than 1 , then the business is profitable and can be run.

\section{2. $\mathrm{R} / \mathrm{C}$ ratio for land area of $1-2 \mathrm{Ha}$}

Calculation of the analysis of the $\mathrm{R} / \mathrm{C}$ ratio in the cultivation of K. alvarezii seaweed in Wajo Regency can be seen as follows:

$$
\begin{gathered}
\mathrm{R} / \mathrm{C}=\mathrm{TR} / \mathrm{TC} \\
\mathrm{R} / \mathrm{C}=\frac{\text { IDR } 199,567,742}{\text { IDR } 74,161,028} \\
\mathrm{R} / \mathrm{C}=2.69
\end{gathered}
$$

Total income received by seaweed farmers in Wajo Regency which is produced is IDR 199,567,742, - and the total cost incurred is IDR 74,161,028, -.

Based on this description, it can be stated that seaweed cultivation is good and can be carried out because the $\mathrm{R} / \mathrm{C}$ ratio obtained is 2.69 , where if the $\mathrm{R} / \mathrm{C}$ obtained is more than 1 , then the business is feasible to run.

\section{Marketing Analysis}

\section{Seaweed Price}

Prices The marketing price of seaweed, both the selling price and the purchase price, is required for marketing margins. Price is an important thing for market players, for seaweed farmers, the price of their production is very influential on the production profits to be obtained. For collectors, the difference between prices and costs determines 
the amount of profit to be received so that this profit becomes the basis for them to make transactions. To find out the buying price and average selling price ofseaweed $K$. alvarezii at each institution, it can be seen in Table 10 below:

Table 10. Buying Price and Selling Price of Seaweed at Marketing Institutions in Wajo Regency in 2021

\begin{tabular}{lcc}
\hline \multirow{2}{*}{$\begin{array}{c}\text { Marketing } \\
\text { Agency }\end{array}$} & Purchase & Sale \\
\cline { 2 - 3 } & $\begin{array}{c}\text { Seaweed } \\
\text { (Idr/Kg) }\end{array}$ & $\begin{array}{c}\text { Seaweed } \\
\text { (Idr/Kg) }\end{array}$ \\
\hline Cultivator & & 21,000 \\
$\begin{array}{l}\text { Collecting } \\
\text { Merchant }\end{array}$ & 21,000 & $22,, 500$ \\
\hline
\end{tabular}

Source: Primary data after being processed, 2021

Based on Table 10 showed that the selling price and the purchase price of seaweed K. alvarezii.selling price for collectors is IDR $22,500 / \mathrm{Kg}$ while the purchase price is IDR $21,000 / \mathrm{Kg}$.

\section{Marketing cost}

Marketing costs are a very important thing to consider in a marketing business because marketing costs include postharvest costs. In accordance with the opinion of Hastuti (2007) cost is the sacrifice incurred by cultivators in managing their business to get maximum results. The following are the marketing costs for seaweed cultivation in table 11 below.

Table 11. Marketing Costs in Seaweed Cultivation Fisheries Business in Wajo Regency in 2021

\begin{tabular}{cc}
\hline Marketing Agency & $\begin{array}{r}\text { Seaweed Marketing Cost } \\
(\mathbf{R p} / \mathbf{K g})\end{array}$ \\
\hline Cultivator & 123 \\
Collecting Merchant & Source: primary data after being processed in 2021
\end{tabular}

Based on table 11. Average marketing costs there is in each marketing agency that is IDR $123,-/ \mathrm{kg}$ in every marketing for collectors where the costs borne by collecting traders are in the form of costs for transportation workers at a cost of IDR 50,000/person in one delivery and the purchase of dried seaweed is usually $10-20$ sacks per purchase, where in one sack contains $80 \mathrm{~kg}$ of dried seaweed.

\section{Marketing Margin}

The marketing margin of seaweed is the difference between the selling price of seaweed and the purchase price. The difference between the purchase price and the selling price in marketing requires a cost so that the costs incurred are expected to be covered from the price difference. For the average marketing margin of Seaweed Aquaculture Business, it can be seen in table 12 below:

Table 12. Marketing Margin in Seaweed Aquaculture Business in Wajo Regency in 2021

\begin{tabular}{lccc}
\hline \multirow{2}{*}{$\begin{array}{c}\text { Marketing } \\
\text { Agency }\end{array}$} & Sale & Purchase & $\begin{array}{c}\text { Marketing } \\
\text { Margin }\end{array}$ \\
\cline { 2 - 4 } & $\begin{array}{c}\text { Seaweed } \\
\text { (Idr/Kg) }\end{array}$ & $\begin{array}{c}\text { Seaweed } \\
\text { (Idr/Kg) }\end{array}$ & $\begin{array}{c}\text { Seaweed } \\
\text { (Idr/Kg) }\end{array}$ \\
\hline Cultivator & 21,000 & & \\
\hline $\begin{array}{l}\text { Collector } \\
\text { merchant }\end{array}$ & 22,500 & 21,000 & 1,500 \\
\hline
\end{tabular}

Source: primary data after processing in 2021

Based on table 12. Average margin obtained by institutions involved in the marketing process. The difference between the prices that collectors pay for seaweed with the price received by seaweed farmers of IDR $1,500 / \mathrm{Kg}$.

\section{Marketing Efficiency}

In the process of marketing a product from the hands of producers to consumers' hands, an institution that will be involved in the marketing process is needed in order to act as an intermediary for the interests of producers and consumers so as not to harm both parties. In this case, the producer considers a trading system to be efficient if the sale brings a lot of profit for him. On the other hand, consumers consider the trading system to be efficient for them if it is easy for consumers to get seaweed at low prices. Asmarantaka (2012) states that the trade system can be said to be efficient if it is able to convey production results to consumers at the lowest possible cost and is able to hold a fair profit sharing from the total price paid by consumers to all parties who participate in production activities.

Table 13. Marketing Efficiency in Seaweed Cultivation Fishery Business in Wajo Regency in 2021

\begin{tabular}{cccc}
\hline \multirow{2}{*}{ Marketing Agency } & Sale & Marketing coost & Marketing Efficiency (\%) \\
\cline { 2 - 4 } & Seaweed (Idr/Kg) & Seaweed (Idr/Kg) & Seaweed \\
\hline Cultivator & 21,000 & & 0.55 \\
\hline Collecting Merchant & 22,500 & 123 & \\
\hline
\end{tabular}

Source: primary data after processed in 2021. 
Based on table 13. above, it can be seen that the marketing of seaweed in Wajo Regency is considered efficient because based on the results of the research, a value of $0.55 \%$ is obtained, which means the value is less than 1 , which is caused by the small number of marketing chains.

\section{Marketing channel}

The marketing channel is a series of paths through which an item passes from the producer to finally reach the consumer. In carrying out marketing activities there are marketing institutions that are passed in carrying out a number of marketing functions. The following is the form of marketing channels in Wajo Regency.

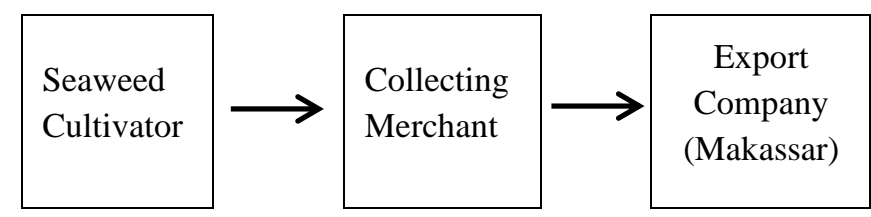

Fig.1. Seaweed (Kappapycus alvarezii) Marketing Channel in Wajo Regency

Based on the marketing channel image,seaweed cultivator Kappaphycus alvarezii as a producer conducts seaweed cultivation business at one time. Seaweed that will be traded is dried before being sold, the drying time is approximately 2-5 days depending on the weather. The dried seaweed is then cleaned of impurities attached to the seaweed, after cleaning the seaweed is put into a sack. After the seaweed is packed into sacks, theseaweed is $K$. alvarezii ready to be sold to collectors, there are also collectors who take it directly to the seaweed farmers.

Collectors sell seaweed at a predetermined market price. Collectors who have purchased seaweed, then store it in warehouses specially made for storing seaweed before being sold to export companies. This warehouse is usually made right next to the house or under the house of the collectors, some also make their warehouses on vacant land owned by the collectors. Before the K. alvarezii seaweed is stored in the warehouse, the previous seaweed is weighed using a sitting scale or a hanging scale. After weighing the seaweed, it is stored in a warehouse.

The seaweed that has been weighed and stored in the warehouse will be sent to an export company in Makassar. From the interview results, the costs incurred by collectors starting from wages for labor and cars (carts), the seaweed that is ready to be brought to Makassar is really dry seaweed so that the price of seaweed received can be high.

\section{CONCLUSION}

The total profit of seaweed cultivators in one year of production is IDR $176,111,484$. Where, on a land area of
$<1 \mathrm{Ha}$, the cultivator earns an annual profit of IDR $50,704,769$, - and for a land area of 1-2 Ha, the cultivator earns profit. per year amounting to IDR 125,406,714, Based on the results of marketing analysis, the marketing costs incurred are IDR $123,-/ \mathrm{Kg}$ for collectors. The marketing margin received by the collecting traders is IDR $1,500,-/ \mathrm{Kg}$. Seaweed marketing in Wajo Regency is considered efficient because based on the results of the study obtained a value of $0.55 \%$, which means the value is less than 1 , which is caused by the short number of marketing chains.

\section{REFERENCES}

[1] Adhawati, S. S., \& Nuryanti, D. M. (2021). Economic Valuation Of Seaweed Cultivation In Mangrove Ecosystem Waters Nunukan District: The Outer Islands Of The IndonesiaMalaysia Border. Plant Archives, 21(1), 1924-1928.

[2] Akil, N., Tetap, D., \& Lpi, S. (2015). Analsis prosfek dan strategi pengembangan komoditi unggulan rumput laut di kabupaten wajo. 439-451. http://repository.ipb.ac.id/

[3] Amiluddin, N. M. (2007). Kajian pertumbuhan dan kandungan karaginan rumput laut Kappaphycus alvarezii yang terkena Penyaki Ice Ice di Perairan Pulau Pari Kepulauan Seribu. http://repository. ipb.ac.id

[4] Anh, M., \& Hanh, H. P. (2021). Marketing and Income Analysis of Seaweed Farming Business. Journal La Bisecoman, 2(3), 17-21.

[5] Asmarantaka, Ratna Winandi. (2012). Pemasaran Agribisnis (Agrimarketing). Penerbit : Departemen Agribisnis Fakultas Ekonomi dan Manajemen IPB. Bogor.

[6] Bangun. (2010). Teori Ekonomi Mikro. refika aditama.

[7] BPS. (2021). Luas Wilayah Kabupaten Wajo. Badan Pusat Statistik.

[8] Cokrowati, N., Nanda, D., Dewi, N. S., \& Alis, M. (2020). Pertumbuhan Rumput Laut Lokal dan Rumput Laut Hasil Kultur Jaringan Kappaphycus alvarezii. Journal of Fisheries and Marine Research, 4(1), 62-65.

[9] Dinas Kelautan dan Perikanan (DKP).2021. Statistik Data Perikanan dan Budidaya Kabupaten Wajo. Diterbitkan setiap tahun

[10] Hastuti, D. R., \& Rahim, A. (2007). Ekonomika Pertanian (pengantar, Teori, dan kasus). Jakarta: Penebar Swadaya,

[11] Nor, A. M., Gray, T. S., Caldwell, G. S., \& Stead, S. M. (2020). A value chain analysis of Malaysia's seaweed industry. Journal of Applied Phycology, 32(4), 2161-2171.

[12] Nurmaena. 2017. Analisis Pola Kemitraan Pedagang Rumput Laut (Eucheuma cottoni) Dari Kalimantan Ke Perusahaan PT. ABC Dan PT. XYZ Di Kota Makassar. Skripsi. Universitas Hasanuddin. Makassar.

[13] Meijer, S. S., Catacutan, D., Ajayi, O. C., Sileshi, G. W., \& Nieuwenhuis, M. (2015). The role of knowledge, attitudes and perceptions in the uptake of agricultural and agroforestry innovations among smallholder farmers in sub-Saharan Africa. International Journal of Agricultural Sustainability, 13(1), 40-54.

[14] Pertiwi, P. (2015). Analisis faktor-faktor yang mempengaruhi 
pendapatan tenaga kerja di Daerah Istimewa Yogyakarta. Yogyakarta: Universitas Negeri Yogyakarta..

[15] Purnamasari, I. A. (2010). Analisis pemasaran jeruk di kabupaten Bangli.

[16] Roni, L. 2016. Alokasi Waktu Kerja Dan Kontribusi Wanita Tani Dalam Meningkatkan Pendapatan Rumah tangga Pada Budidaya Rumput Laut di Desa Lambelu Kecamatan Pasikolaga Kabupaten Muna. Skripsi. Universitas Halu Oleo. Kendari.

[17] Sellers, J. Andrew, dkk. 2015. The Introduced Alga Kappaphycus alvarezii (Doty ex. P.C.Silva.1996) In Abandoned Cultivation Sites In Bocas Del Toro, Panaman. BioInvations Records (2015) Volume 4, Issue $1: 1-7$

[18] Singarimbun, M. d. (2008). Metode Penelitian Survei. Jakarta: Pustaka LP3ES.

[19] Soekartawi. (2006). Analisis Usahatani. universitas indonesia. Jakarta

[20] Sugiyono. (2013). Metode Penelitian Kuantitatif, Kualitatif dan $R \& D$. Bandung: Alfabeta.

[21] Le Gouvello, R., Hochart, L. E., Laffoley, D., Simard, F., Andrade, C., Angel, D., ... \& Marino, G. (2017). Aquaculture and marine protected areas: potential opportunities andsynergies. Aquatic Conservation: Marine and Freshwater Ecosystems, 27, 138-150. 